\title{
9 機械的嵌合技術によるハイブリッド化*
}

Hybridization of Cylindrical Structures by Mechanical Fitting Processes* (Thermo Elastic Plastic Processing)

キーワート：熱拡管法，環熱縮管法，機械的嵌合，耐食二重管， 耐摩耗二重管

\section{1. ま がき}

最近各種機器, 構造物などの工業製品の性能も 高度でしかも複数の機能が要求される場合が増え て来ている. 構造材料の基本の一つである管構造 体に拈いても，その用途が広がってきたのに伴っ て，過酷な条件で使われるケースが增えて来てい る. 高強度, 高耐食性, 高耐摩耗性や断熱性能な どが求められている，例えば高深度油井管には高 強度, 高耐食性が要求される.また微粉粒等の高 速搬送管には高い摩耗性が要求される. 高耐食管 には高ニッケル合金一層単管などがあるがコスト

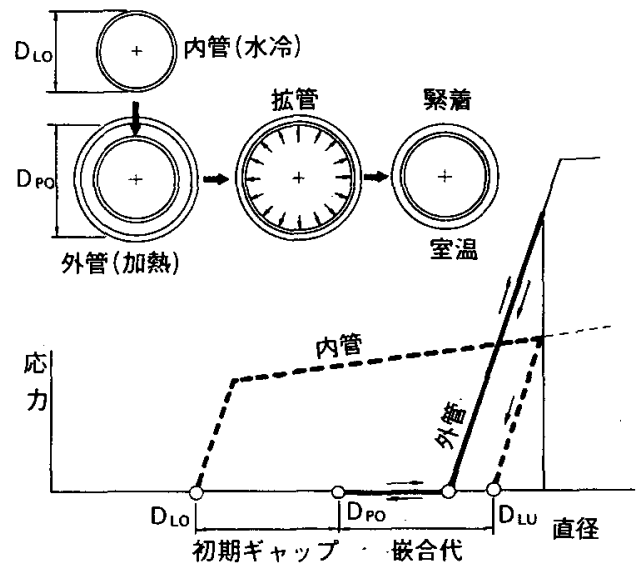

図 1 熱拡管法の概念と嵌合応力の発生機構

\footnotetext{
*原稿受付 昭和63年 3 月31日

**正員 川崎重工業(株)技術研究所

KAW ASAKI HEAVY INDUSTRIES, LTD.
}

や強度の問題があり，低コストで高・多機能管の 実用化が求められている.

管の高機能化のための手段として，例えば高強 度・高耐食性管の場合高強度の外管に耐食性に富 んだニッケル合金やステンレス管を内張りした二 重管のアイデアがある.

重層管製造技術として一般的に次のようなもの がある。

\section{冶金的結合管一熱間押し出し法 \\ (クラッド管) 内面肉盛溶接法 \\ HIP 法 \\ 鋳くるみ法}

接着等による一内, 外面エポキシ等の樹脂コーテ

$$
\text { ライニング管 ィング法 }
$$

機械的嵌合管一楛きばめ法 压入法

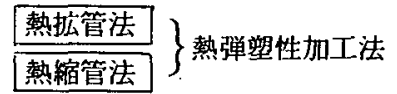

ステンレス鋼と炭素鋼管との複合において，治 金的重層をするため高温で熱間押し出しや肉盛溶 接をした場合，製造後の熱処理においてステンレ ス鋼向けの固容体化処理 (急冷) 之炭素鋼向けの 焼き入れ焼ならし熱サイクルは原則的に相入れな い屯ので，どちらかの材料の性質を犠牲にせざる を得ない，組合せ材料の本来の特性を損なわずに 複合化出来，しかす管として一体挙動する特性を あたせると共に長尺の管が容易に製造できる技術 が必要である．ここで素材の特性を維持し，しか あ展尺管が安価で製造できる新しい機械的嵌合多 重管の製造法とその適用例について述べる. 


\section{2. 熱拡管法一内管が拡管して 外管に緊着する方法}

従来二重管, 三重管を作る方法として焼きばめ法 (冷しばめ法) があるが，乙の方法は，はめる前に 精度の高い管の寸法仕上精度が必要なととと, 長尺 管を製造することが難かしい，そてで新しく焼きば め法と水圧拡管法を組合せた熱拡管法 (ThermoHydraulic Fitting Method）と呼ぶ複合管製造 方法を開発した ${ }^{1-3)}$. 本方法は図 1 にその原理を 示すように，加熱して膨張した外管に，挿入が容 易な寸法の内管を，その内管の内部を通水して内 管温度を水温に保った状態で挿入し，内外管に温 度差をつけた状態で水圧拡管する方法で水圧を開 放し，内外管は弾性縮径するあどり差と外管が室 温まで冷却する時の熱収縮とによって高い嵌合応 力を有する緊着二重管を作る方法である.

写真 1 亿熱拡管装置の外観写真, 図 2 亿熱拡管 過程での内外管の温度および拡管圧力の履歷を示 す. 外管が所定の加熱温度に達した時点で短時間 （1～2 秒）に拡管圧力を増圧すると, 拡管圧

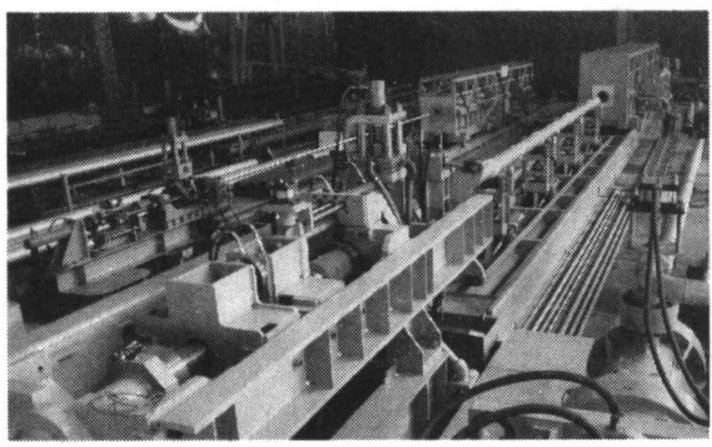

写真 1 長尺複合管製造用熱拡管装置

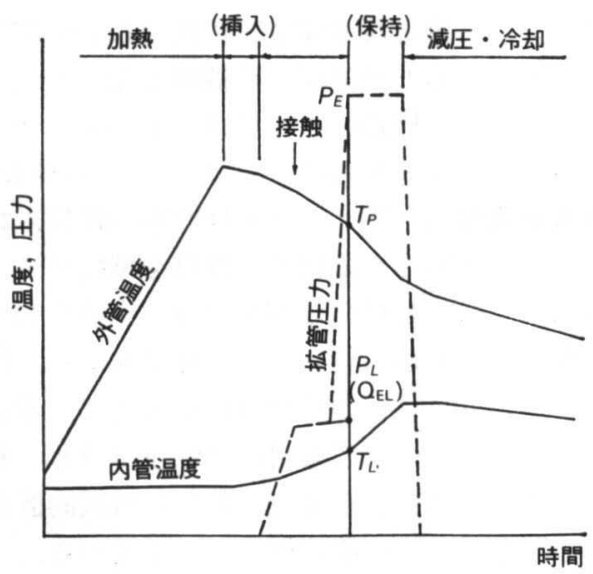

図 2 熱拡管過程の拡管圧力と内外管の温度変化履歴
$\mathrm{P}_{\mathrm{E}}$ で内管が塑性変形して内管と外管が接触し, その後内外管が一体となって拡管され, 所定の拡 管圧 P で短時間保持した後, 圧力を開放し, 内 管内の冷却水（拡管用圧力媒体兼用）を流水する. 内外管が接触した後, 内管と外管の温度差は急速 に一様となり, 室温にまで冷却されると, 内外管 は十分に嵌合される.

内外管の嵌合の程度を示す指標として, 内管に 残留する周方向の圧縮応力を採用し，乙れを麻合 応力 $\sigma_{\mathrm{F}}$ 之呼ぶ. 嵌合応力 $\sigma_{\mathrm{F}}$ は内外管の管寸法

(板厚 $\mathrm{t}$, 外径 D) 之降伏応力 $\left(\sigma_{\mathrm{E}}\right)$, 加熱温度 (T) ヤング率 (E) と線膨張係数 $(\alpha)$ および拡 管圧力 $\left(\mathrm{P}_{\mathrm{E}}\right)$ によって次式に表される.

$$
\begin{aligned}
& \left.\sigma_{\mathrm{P}}=\mathrm{t}_{\mathrm{P}} /\left(\mathrm{t}_{\mathrm{L}}+\mathrm{t}_{\mathrm{P}}\right) \cdot\left\{\alpha_{\mathrm{P}} \mathrm{TE}+\mathrm{D}_{\mathrm{P}}-2 \mathrm{t}_{\mathrm{L}}\right) \cdot \mathrm{P}_{\mathrm{E}} / 2 \mathrm{t}_{\mathrm{P}}\right\}-\sigma_{\mathrm{EL}} \\
& \mathrm{P}_{\mathrm{E}}=2\left(\mathrm{t}_{\mathrm{L}} \sigma_{\mathrm{EL}}+\mathrm{t}_{\mathrm{P}} \sigma_{\mathrm{EP}}\right) /\left(\mathrm{D}_{\mathrm{P}}-2 \mathrm{t}_{\mathrm{P}}-2 \mathrm{t}_{\mathrm{L}}\right) .
\end{aligned}
$$

ここで，添字 P は外管，L は内管を表す.

嵌合応力は主として外管と内管との温度差 $(\mathrm{T})$ と拡管圧力 $\left(\mathrm{P}_{\mathrm{E}}\right)$ の組合せを適宜選定すること によって所要の値に容易に制御出来る製造方法で ある.

適用例として, 外管に高強度な高張力鋼管を内 管に高ニッケル合金管を組合せるてとによって高 強度・高耐食管が製造できる. 製品は硫化水素等 の腐食性ガスを含有する石油, ガス用深井戸用油 井管や輸送パイプラインに適用されている（写真 2 参照).

\section{3. 熱縮管法一一外管が縮径して 内管に緊着する方法}

高炭素鋼, 高クロムマンガン鋼やセラミックス のような耐摩耗材を内管にする場合, 材料そのむ

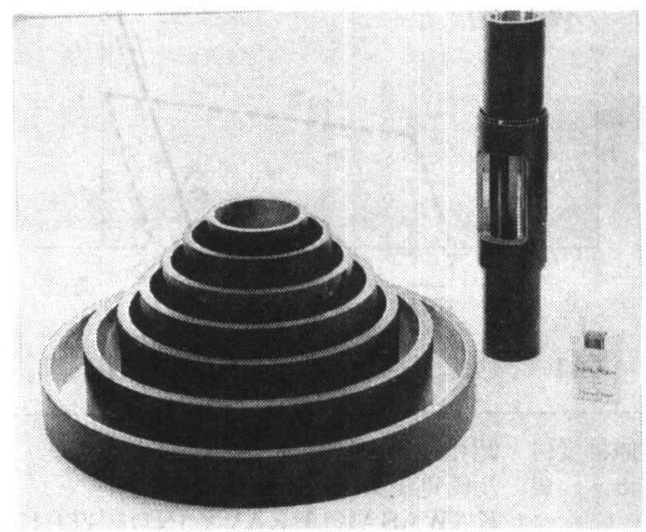

写真 2 石油・ガス輸送用パイプと油井管（高耐食 性二重管) 
のが硬度が高く，延性に己しいととより，外管に なる炭素鋼管等の金属管を縮径させ，内管材に緊 着させる万法として熱縮管法（Ring Heat Shrink Method）を開発した 部加熱, 冷却する処理を管長手方向に連続して施 すことにより，管径が変化する．図 3 は，乙の処 理状況を模式的に示したものであるが，乙の現象 は，図 4 に示すような熱弾塑性挙動に起因する. すなわち，管の局部を加熱すると，加熱部は熱膨 張により膨径しようとするが，周辺の冷却部によ り変形が拘束され，自由膨張する場合に比へ膨径 量は小さくなる，乙のとき，加熱部は降状点が低 下していることと相伴って塑性変形し，その後冷 却すると熱収縮により，乙の部分の径は初期径よ り小さくなる．とのような，加熱・冷却処理のみ で管径を変化させる処理を環熱縮径法 (Ring Heat Sirink method : RHS 法) と呼ぶ.

図 5 は，RHS 法により管径が変化する現象を，

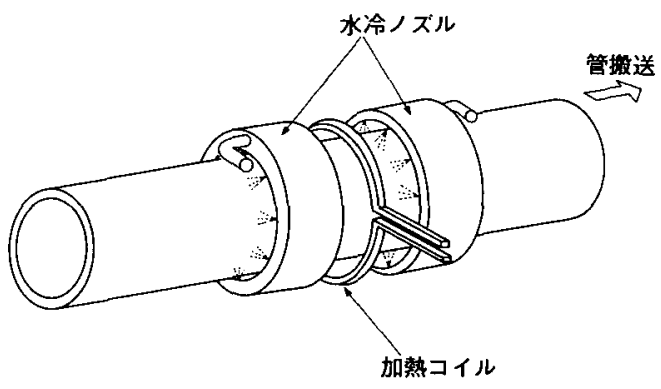

図 3 環熱縮管法の模式図

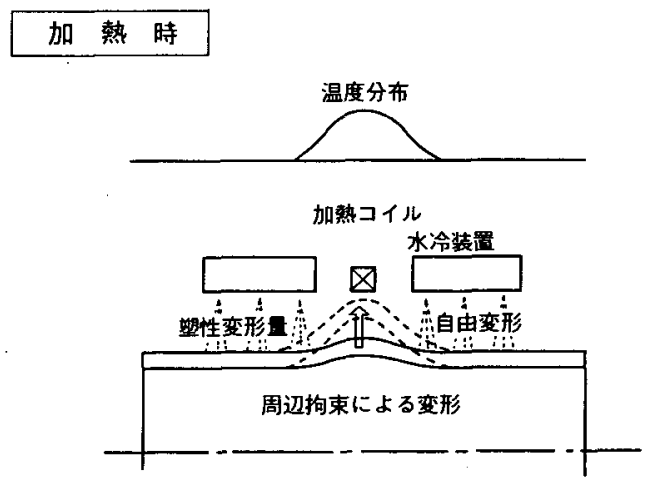

冷 却 後

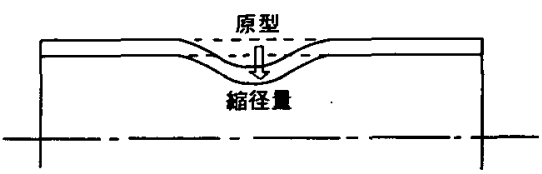

図 4 局部加熱・冷却による管の变形挙動
熱弾塑性解析により評価したもので，炭素鋼管に 対し， $800^{\circ} \mathrm{C}$ まで加熱し，冷却する処理を管の長 手方向に連続して施した場合の管径の過渡的変化 を示したあのである，乙の場合，与えられた熱源 の温度分布に応じ，管径が変化するととむに，周 辺部の拘束に上り塑性歪が発生し, 熱源の通過後 には，管は縮径しているととが認められる。

てのように，RHS 法は，管に対しなんら外力を 加えることなく管径を変化させることができ，広 く工業的仼適用できる熱塑性加工法の 1 つである といえる.

RHS 法を利用した製品群に，機械的に緊着し た二重管がある.乙れはあらかじめ内管を挿入し た状態で，RHS 法により外管を縮径し，内外管 を嵌合させ，二重管を製造するもので，従来，嵌 合二重管の代表的製造方法である焼きばめ法と比 較した場合，嵌合面での高精度な仕上げ加工が不 用であり，かつ製造可能な管の長さなどの形状の 制約がなく，更に，直管のみならず曲管も製造が 可能であり，その適用範囲は広い，

図 6 は，RHS 法を利用した二重管製造におい て, 処理でとの外管の径変化と内外管の嵌合度変 化の一例を示したもので，処理回数が増すにつれ， 外管の縮径量は增大し, 内外管が接触後, 嵌合度 が増大していくことがわかる，てのように，RHS 法を利用した二重管製造技術は，以下の特徴を有 している.

(1) 内外管の嵌合面に高精度加工が不用である.

(2) 二重管形状・材質に制約されない.

(3) 処理回数を変えることで，嵌合度を変える ことができる.

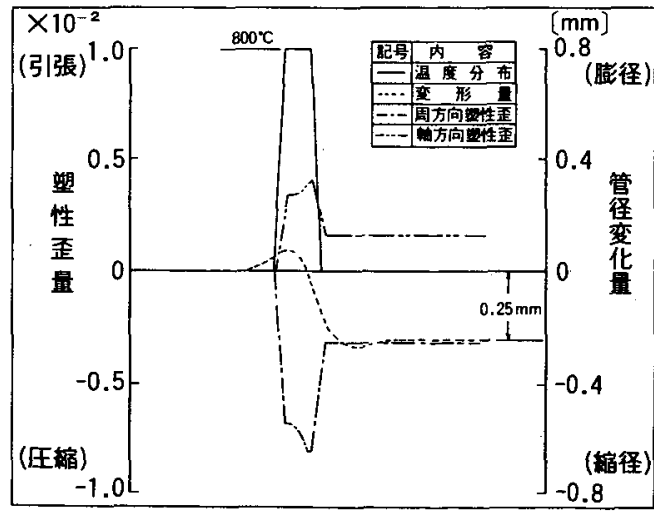

図 5 RHS 法による管の変形挙動に関する解析例 （軟鉿管：直径 $165 \mathrm{~mm}$ ，管厚 $5.5 \mathrm{~mm}$ ) 
RHS 法の適用例として, 耐摩耗性を要求され る配管部材用に，RHS 法を利用して，内管に高 耐摩耗材料である各種セラミックス管を用いた二 重管を試作した例を写真 3 に示す. このように, 従来, 勒性に乏しく，構造用部材として使用する ことが難しいとされていたセラミックス材料に金 属管を重層するてとによって靶性・強度を付与し, セラミックス材自身の特長を十分に活かした高機 能管を製造することができる，製造された直管， 曲り管の耐摩耗管は従来の金属管の寿命を大幅に 改善した。

RHS 法は, 熱サイクルの回数, 加熱温度の制

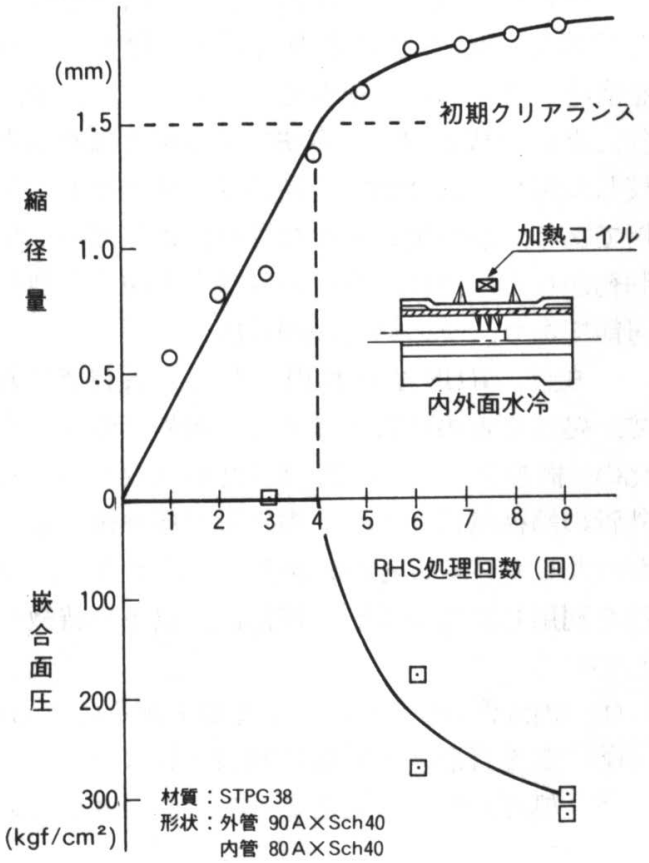

図 6 環熱縮径処理による管の縮径とそれにとあな う嵌合面圧の発生

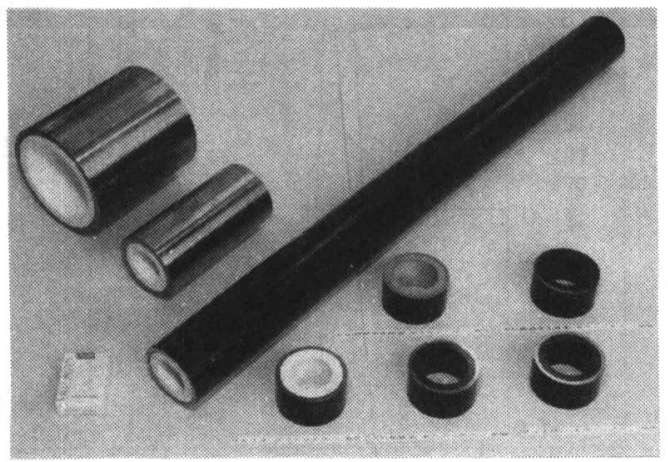

(a) 真 管
御によって嵌合度合は自由にコントロール出来る こと，二重管のみならず多重管も製造可能である ことなどからその適用範囲は広く，各種の高機能 管の製造に活用される。

\section{4. あとがき}

以上，熱弾塑性加工として新しく開発された管 の複合化技術を紹介したが，前者は熱膨張・収縮 変形と水圧成形法を複合したてとにより，精密成 形と焼きばめを同時化した加工法と云える，後者 は溶接変形問題等に係わる金属の局部加熱による 熱弾塑性変形挙動を加工法として積極的に利用し たもので，何ら直接外力を加えずして管を変形さ せる技術である．また前者は内管が拡管して外管 に緊着する方法で，後者は外管が縮管し内管に緊 着する方法であり，緊着すべき内管，外管の材質 によって使いわけることが出来る. 両方法は材料 の組合せに制限はない，現在，耐食，耐摩耗二重 管として製品化されているがてれ以外の管構造体 の機能化，複合化等に広く適用されている.

\section{参 考 文 献}

1) T. Yoshida, S. Matsui et. al : Corrosion problems of pipeline and a solution; Offshore Conference Technology OTC 3891 (1980), pp 361-370

2) T. Yoshida, S. Matsui et. al : The development of corrosion resistant tubing; Offshore Conference Technology OTC 4153 (1981), pp 365-378

3) T. Yoshida, S. Matsui et. al : The development of a joint for metal-lined tubing ; Offshore Conference Technology OTC 4200 , pp 397-412

4) 荒田吉明編, 高温工学, 日刊工業新聞社発行, 昭和63年 4 月, pp. 247 273

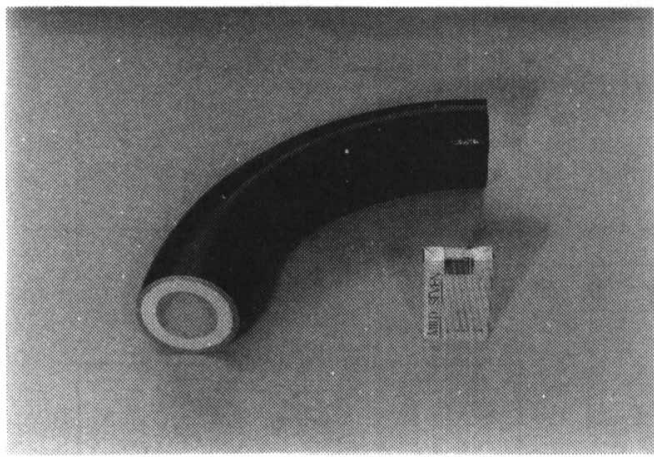

(b) 曲り管

写真 3 セラミックスを内管とした耐摩耗二重管 